\title{
Processos de cura com ervas da terra: saberes de uma Doutora Raiz
}

Healing processes with ground herbs: knowledge of "Doutora Raiz"

Cristina Diógenes Souza Bezerra Mestranda em Antropologia Social -PPGAS/UFRN cristina.dsb@gmail.com 
Resumo: O artigo trata a partir da ideia de sistemas locais de saber, utilizada por Shiva (2003) e saber local por Geertz (2009), para abordar sobre os processos de cura com as ervas da terra. No qual analisa a interação entre os conhecimentos, ditos do senso comum, que não correspondem ao globalizado, mas estão espraiados. Demonstrando as capacidades desses sistemas locais de saber, Vandhana Shiva aponta para a manutenção da vida, para a potencialidade de utilizar as espécies nativas nos processos de cura. Assim sendo, percebe-se a partir dos relatos da história vida de Francisca, esses conhecimentos e práticas de cura. A habitante do bairro do Pium, Parnamirim/RN, reconhecida enquanto Doutora Raiz explicita a produção de saber local e a crença no conhecimento para a eficácia terapêutica com as ervas que curam. As narrativas abordam sobre experiência da doença crônica, artrite reumatóide, na qual gerou uma ruptura biográfica, dentre outros eventos-críticos apontados por Veena Das (1995). Considerando que as narrativas ocorrem de maneira descontínua, somos remetidos nessa etnografia à uma análise o próprio processo de construção da identidade de Doutora Raiz. Com efeito, as narrativas nos levam à histórias de família que, como explanou Pina Cabral (2005), com experiências multifacetadas preenchidas de expressões emotivas explicitam práticas cotidianas que transcendem histórias de família individuais. E nesse caso, são histórias permeadas pelas práticas de cuidado em saúde nas experiências da doença, pelo saber, intenção e eficácia terapêutica com as ervas da terra.

Palavras-Chave: Saber Local; Ervas da Terra; Experiência da Doença; Eficácia Terapêutica.

Abstract: The article deals with the idea of local systems of knowledge, used by Shiva (2003) and local knowledge by Geertz (2009), to discuss the healing processes with the ground herbs. In which analyzes the interaction between knowledge, sayings of common sense, which does not correspond to the globalized, but are broadcasted. Demonstrating the capabilities of these local systems of knowledge, Vandhana Shiva points to the maintenance of life, to the potentiality of using native species in healing processes. Therefore, one can perceive from the narratives of Francisca's life history, these knowledge and practices of healing. The resident of the neighborhood of Pium, Parnamirim/RN, recognized as Doctor Raiz explains the production of local knowledge and the belief in the knowledge for therapentic efficacy with herbs that cure. The narratives address the experience of the chronic illness, rheumatoid arthritis, which generated a biographical disruption, among other critical events aim by Veena Das (1995). Considering that the narratives occurred in a discontinuous way, we are referred in this ethnography from an analysis about the process of identity construction of "Doutora Raiz". In fact, the narratives lead us to the family story, as explained by Pina Cabral (2005), with multifaceted experiences filled with emotive expressions that explain everyday practices that transcend individual family histories. And in this case, are stories permeated by the practices of bealth care in the illness experience, by the knowledge, intention and therapeutic efficacy with the ground herbs.

Keywords: Local Knowledge; Ground Herbs; Illness Experience; Therapeutic Efficacy 
"O primeiro plano da violência desencadeada contra os sistemas locais de saber é não considerá-lo um saber. A invisibilidade é a primeira razão pela qual os sistemas locais entram em colapso, antes de serem testados e comprovados pelo confronto com o saber dominante do Ocidente." (Vandana Shiva, Monoculturas da Mente, 2003)

Os sistemas locais de saber podem ser invisibilizados pelo saber dominante, científico, inclusive nas pesquisas acadêmicas, por não serem percebidos enquanto um saber. Entretanto, em Monoculturas da Mente, Vandana Shiva (2003) revela que esse saber que se propõe globalizado é também advindo de um local com classe e gênero específico. Assim, ela aponta para as capacidades desses sistemas locais de saber, desde a manutenção da vida, à também de reconhecer as potencialidades das espécies nativas e utilizá-las nos processos de cura com maestria. Valorizando a variedade vegetal como uma riqueza na qual não há a concepção de ervas daninhas, de mato. Elas não atrapalham a produtividade, elas são vistas como ervas da terra que constituem uma farmácia em cada esquina, e também interagem com o avanço da biotecnologia, do saber científico nas matas e nos corpos.

Este artigo sintetiza aspectos desenvolvidos no trabalho monográfico Saber local e práticas terapêuticas da Doutora Raiz: uma pesquisa antropológica sobre medicina popular e crença (BEZERRA, 2016) ${ }^{1}$, no qual a partir da trajetória de vida e das narrativas de Francisca foi abordada a relação do conhecimento científico e popular, a experiência da doença (LANGDON, 2014) com a importância da fé e do acreditar para a eficácia terapêutica (TAVARES; BASSI, 2012).

Francisca hoje é reconhecida no bairro que habita, Pium município de Parnamirim/RN, como mulher das ervas ou Doutora Raiz, pela sua sapiência com as ervas que curam e pela capacidade de transformá-los em remédios naturais. 


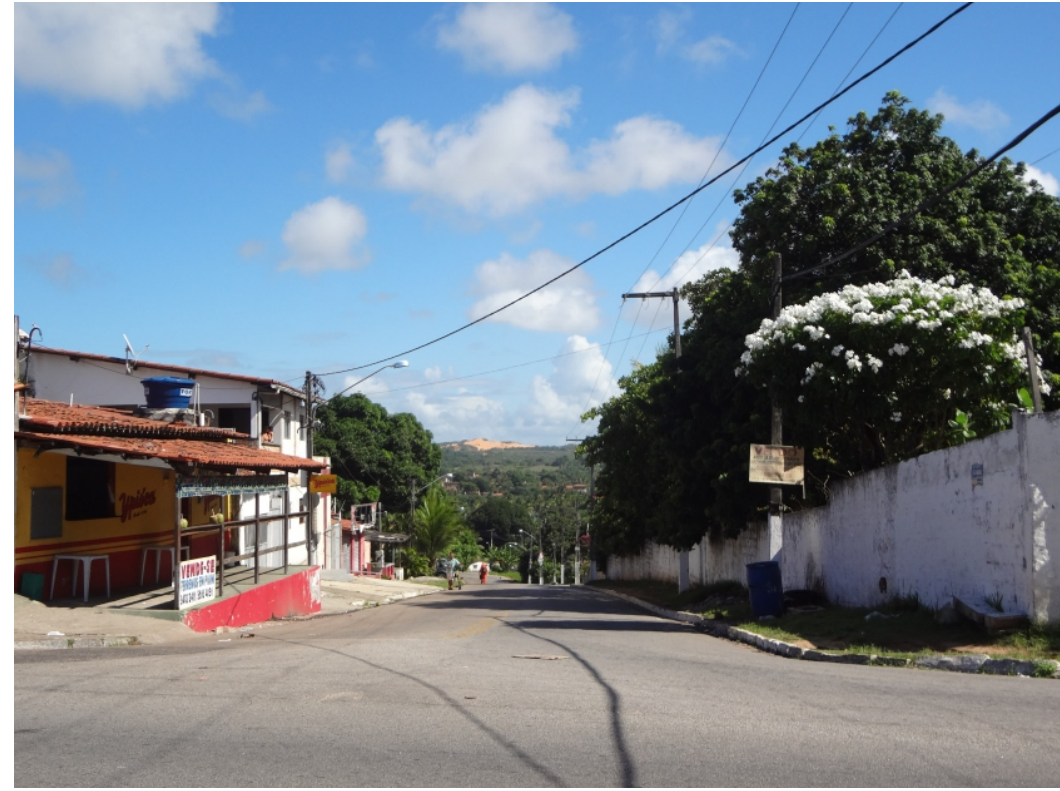

Foto 01: Descida que dá acesso ao Rio Pium, local que faz parte das narrativas da interlocutora e divide os municípios de Pium e Nísia Floresta. Arcevo Pessoal. Maio de 2016.

É na busca dos sistemas de saberes locais para a manutenção da vida que esse artigo se desenvolve. A saber, o termo utilizado acima ervas da terra, se expressa enquanto uma categoria nativa, da interlocutora, um saber local (GEERTZ, 2009) associado às ervas que curam que exprimindo a percepção de uma farmácia em cada esquina, faz referência aos livros que consulta, por exemplo, O poder de cura do limão (TRUCOM, 2014). Para compreender os fatores que constituem tal realidade social trataremos aqui alguns de seus relatos de vida (ALBERTI, 2004):

F: Eu nasci em Bento Fernandes. Sertão lá. É aí em João Câmara, na baixa verde, que era baixa verde hoje é Riachuelo. Eu nasci e me criei lá.

C: Seus pais trabalhavam na agricultura?

F: Meus pais trabalharam e me criaram na agricultura. Depois de 8 anos, 12 anos, 13 anos eu trabalhava na agricultura, tanto é que não estudei por que trabalhei na agricultura. 8 anos de idade era nos partidos de algodão, apanhando algodão no quilo pra vender depois na semana, era socando dentro do saco. (...) A gente era entrando no saco e socando pra caber mais algodão. Menina, era eu e minha irmã, a gente ia pro roçado tão cedo. Pra apanhar o algodão serenado que pesa muito, de manhãzinha a gente saia colhendo as lã. "O que vocês fazem nesse algodão? Bota pedra é?" Toda vida eu dei valor a essa coisa da agricultura, por que é a coisa que você ver, plantar, colher, é muito bom, sabia? Não tem agrotóxico, come coisas natural, do colhido do roçado. (F., entrevista, 18/09/2015, Parnamirim) 
Por esse relato percebemos que Francisca cresceu no meio rural em contato com o cultivo das plantas, trazendo conhecimento e experiências sobre o natural, a partir de um saber local imerso na prática cotidiana.

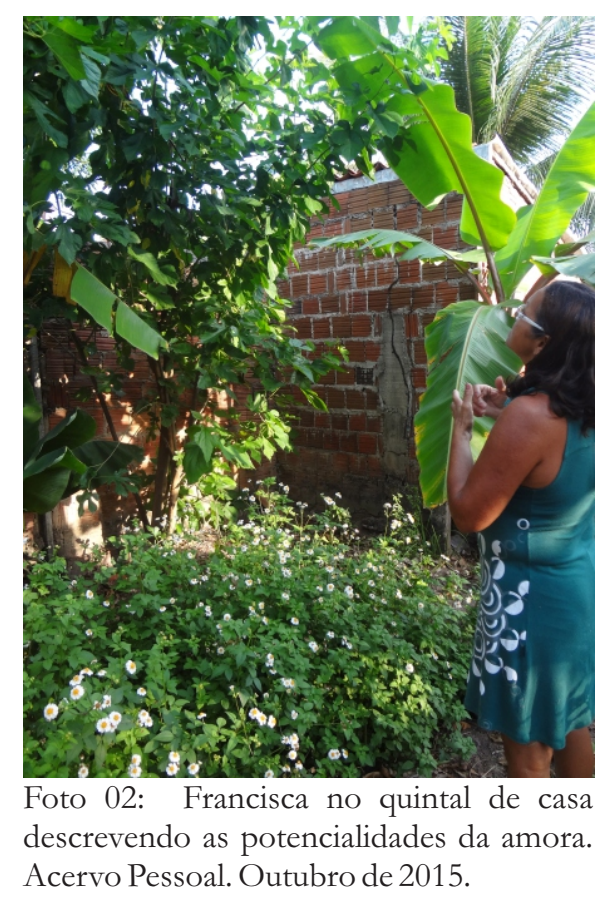

Isto nos atenta para o que Bourdieu (1986) aborda e Pina Cabral e Lima (2005) elaboram ao estudarmos as trajetórias de vida e histórias de família, no que concerne ao fato de que produحir uma história de vida enquanto algo coerente é uma ilusão, pois o real é descontínuo, logo as narrativas elaboradas são situacionais. A análise que encontrada o decorrer deste artigo leva em consideração que a atividade científica é uma atividade social, no qual os elos humanos estão envolvidos no processo de criação científica, de tal forma que as histórias reveladas teriam outro aspecto a depender do modo como foi estabelecida a relação intersubjetiva entre a pesquisadora e a interlocutora.

Como apontou Pina Cabral (2005) na etnografia de uma trajetória de vida, somos perpassados pela história de família, e não encontramos apenas um relato de fatos, mas experiências vividas e multifacetadas, permeadas por expressões emotivas que revelam modos de relacionamento e interpretação do mundo e que dão forma às práticas cotidianas dos sujeitos e transcendem amplamente as histórias de família individuais. 
Essa possibilidade de encontrar nas narrativas uma multiplicidade de experiências permite refletir sobre a interação dos sistemas de saberes. Geertz (2009) auxilia na discussão de como estudos antropológicos lidam com o conhecimento das realidades que se debruçam, e nos faz perceber que a questão da pesquisa não é encontrar a forma elementar da ciência nos mais simples, mas "de saber até que ponto, nesses vários lugares, os aspectos da cultura foram sistematizados, ou seja até que ponto eles têm subúrbios" (GEERTZ, 2009, p.30). Assim ele faz notar a dimensão da cultura, que não é plausível nas pesquisas científicas e nem percebida como sistemática: o senso comum. Por conseguinte, exalta características inerentes ao pensamento que resulta do senso comum, expondo que a sabedoria coloquial tem critérios de inteligência, discernimento, reflexão prévia, e isso faz com que se trate dos problemas cotidianos com alguma eficácia. $\mathrm{O}$ autor nos revela que os argumentos do senso comum, não baseiam-se em coisa alguma, somente na vida como um todo, e assim evidencia a sistemática do pensamento, da tomada de decisões, das conclusões, colocando a percepção do bom senso como a interpretação de uma realidade imediata. Pois tal como a pintura, a epistemologia também é construída historicamente, forjando então, como apontou Geertz (2009), um sujeito com padrões de juízo definidos também historicamente.

É nessa valorização da sabedoria, do discernimento, da reflexão prévia, do tornar visivel (KLEE, 1961 apud INGOLD, 2015) que reconheci em Francisca uma pesquisadora, agente terapêutica da comunidade do Pium e arredores, que a partir da experiência cotidiana, daquilo que não foi ensinado, mas foi experienciado, facilita processos de cura por meio da crença e do conhecimento, tratando problemas de saúde com uma eficácia terapêutica reconhecida no bairro e fora dele.

O modo que ela aprendeu foi pela observação, pesquisa e pela prática, nos remetendo ao conceito de habitus, em Bourdieu (2004) e lembrando a discussão que Lévi-Strauss suscita, em seu artigo $A$ ciência do concreto, que mostra como as pessoas, devido ao enorme interesse e a atenção apaixonada, desenvolveram um extenso repertório etnobotânico e sistematizaram um saber não só pela necessidade de utilização, mas também pela necessidade de classificação do meio biológico (LÉVISTRAUSS, 1976). Na experiência de vida narrada por Francisca ao longo da sua infância as doenças que apareceram foram curadas por sua a mãe e avó preparando remédios com a variedade botânica local, inclusive com algumas espécies que até hoje são 
desconhecidas para Francisca. Tratam-se, então, de saberes repassados de maneira geracional, embora haja também informações não transmitidas, principalmente aos doentes em relação ao que havia dentro dos chás.

Tratamos aqui de um estilo de vida, de uma moral, de processos de cura de uma especialista terapêutica que, assim como Muchona, desde que nos conhecemos responde "pronta e longamente, com o brilho do entusiasmo verdadeiro" (TURNER, 2005, p. 180). Brilho esse registrado nas entrevistas realizadas na cozinha de sua casa, tal como aconteceu no dia 18 de setembro de 2015:

C: A dúvida que eu tenho é tipo assim, o que a senhora conseguiu aprender com sua mãe. Que é que ela lhe passou, entendeu? Se ela fazia as coisas sozinha do jeito que a senhora faz?

F: Não, assim, isso aí já vem da minha avó. A minha mãe já trouxe isso pra gente, já passou por a gente, já criou nessa sabedoria. De plantas, de remédios, se você tava doente, corria ali no mato procurava uma planta. Que foi? Isso assim é bom pra isso, isso e isso. E ela corria atrás daqueles remédios, daquelas ervas. E a gente não tinha farmácia por perto, não tinha médico e a gente se cuidou dessas coisa de planta. Pra você ver, ela teve onze filhos, só teve um na maternidade, que ficou enlaçado não nasceu. Tudo era em casa, a parteira vinha, acompanhava, e a gente foi criando naquela coisa, e criando aquela vida de coisas natural. Então eu gravei!

C: Então, quando ela ia no mato a senhora ia com ela?

F: Então eu gravei as plantas, isso daqui é chá disso assim assim assim, que é bom pra isso e isso. Aí eu fui gravando as plantas, aí depois que a gente cresceu que foi se acostumando, a coisa era difícil na mesma coisa, que tudo de remédio, eu não tinha remédio, não tinha dinheiro pra comprar, apelava pro chá, pras plantas, hortelã, mastruz com leite, essas coisas, tamarina.

C: Matruz com leite dá força é?

F: Não, mastruz com leite protege os brônquios, o pulmão e você tá com gripe muito forte, cansada, pegada, colada no intestino, com começo de pneumonia você vai fazer mastruz com leite, a criança toma ou o adulto, ele já vai largado. O remédio e tomar um banho logo cedo, nós fomo criado assim, no interior, tomar remédio pra gripe, vamos tomar banho logo cedo, todo mundo ia pro rio, tomava o remédio e tomava banho no rio logo cedo". (F., entrevista, 18/09/2015, Parnamirim). 


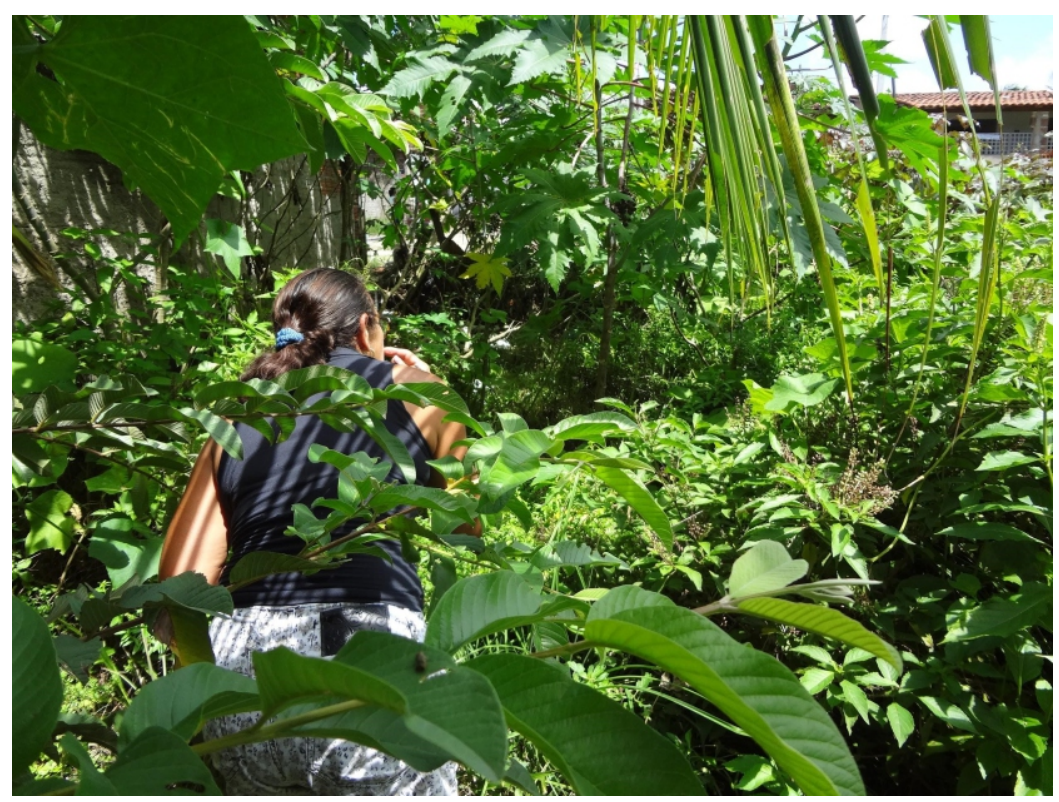

Foto 03: Francisca em um terreno localizado atrás da sua casa, à procura de uma planta chamada mussambê. Acervo Pessoal. Maio de 2016.

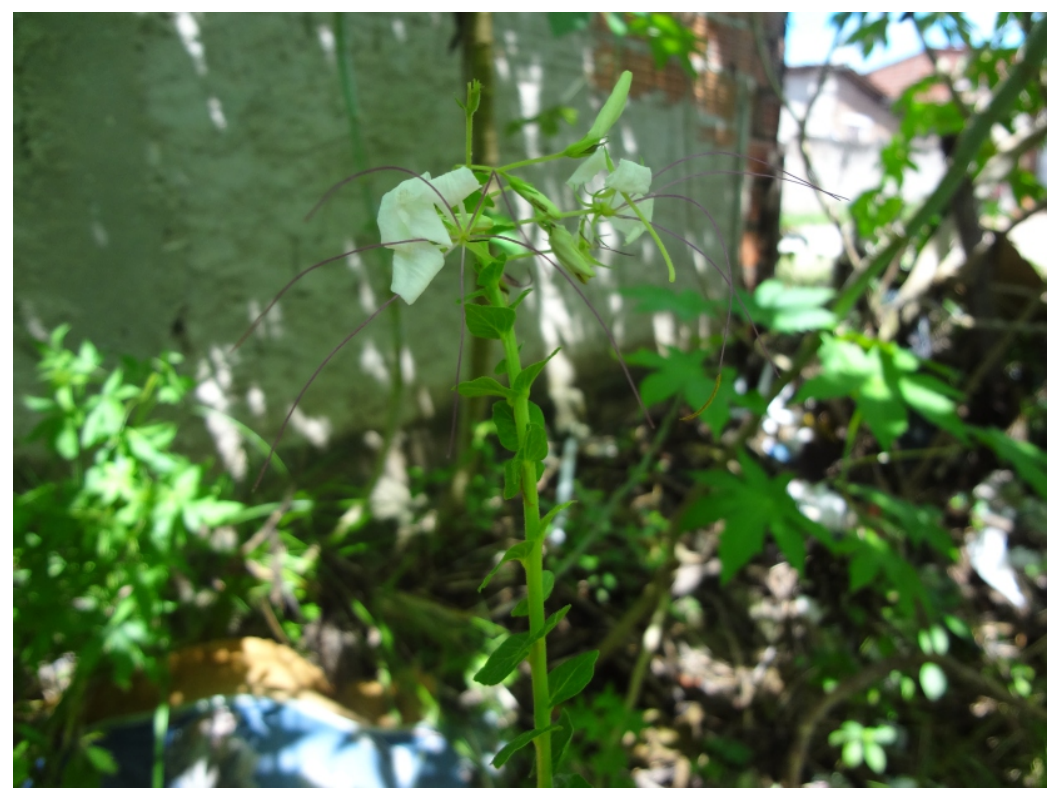

Foto 04: Mussambê (Cleome hassleriana), planta utilizada para ferimentos, bronquite. Acervo Pessoal. Maio de 2016.

Esse relato mostra o conjunto de relações que embasam esta prática terapêutica, uma sabedoria que passa pelas gerações, com "técnicas que supõem séculos de observação ativa e metódica" que, para sua elaboração, exigem "uma atitude de espírito verdadeiramente científica, uma curiosidade assídua e sempre desperta, uma vontade de conhecer pelo prazer de conhecer" (LÉVI-STRAUSS, 1976, p. 30). Além do conhecimento elaborado a partir da vivência com mãe e avó nas 
experiências da doença e processos de cura, ela recorre aos livros científicos e se reporta a esse prazer de conhecer, fato que será desenvolvido no decorrer do artigo.

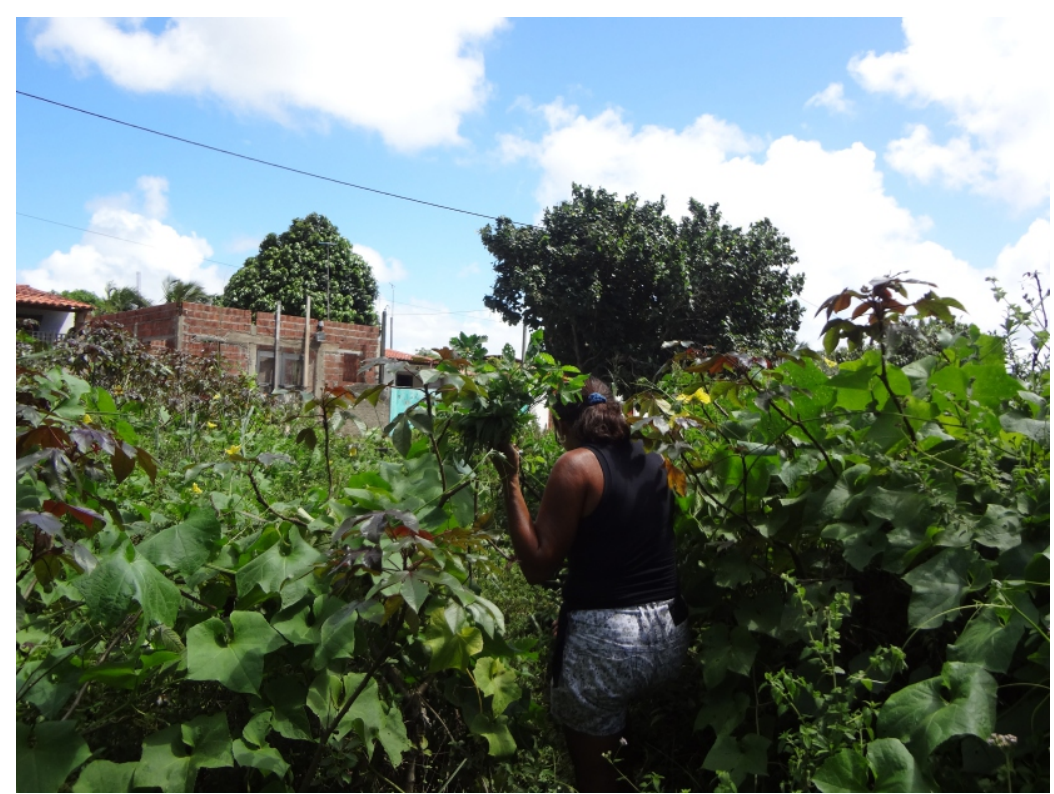

Foto 05: Saída da mata atrás da sua casa, margeada por plantas de pião roxo, bucha. Acervo Pessoal. Maio de 2016.

Em suas narrativas é notória a presença da mulher como eixo central da transmissão desse saber, reforçando a presença das cuidadoras, as mães, esposas e irmãs (NÓBREGA, 2011; SCOTT; QUADROS, 2009) no terreno do popular, que nesse caso habita o meio rural, integralmente "natural", que permite desenvolver práticas terapêuticas a partir das ervas da terra por meio de inalações, pomadas e alimentos e que se mantém longe da prática médico-hospitalar por fatores socioeconômicos, pela falta de acesso a farmácias ou atendimento médico. Ao longo de sua trajetória ela se deparou com a inexistência ou ineficiência da prática médica alopática e as dificuldades de ir ao hospital, e em diversos momentos da sua vida Francisca preferiu ou precisou realizar os tratamentos em casa.

Há um caso marcante, contado de modo recorrente, que é o adoecimento do filho mais novo, Rodrigo, que aos 7 meses teve pneumonia, ficou internado no hospital um mês e a médica recomendou tirá-lo de lá pois corria o risco dele piorar pelo contato com as outras crianças no ambiente hospitalar. E nessa ocasião uma senhora que estava no corredor escutou a conversa e aconselhou Francisca a fazer um lambedor de tamarindo com beterraba e cenoura, e ela assim agiu. 
Essa situação a fez recorrer e aprender modos tradicionais de cura pelo uso de plantas, passando a produzir o lambedor, inserindo alimentos específicos, e utilizando os banhos de rio que aprendeu na infância, precedidos pelo mastruz com leite, ela se apropriou de práticas terapêuticas e inseriu no seu cotidiano. Atrelado a essa situação, há um caso também muitas vezes narrado, ocorrido quando ela chegou ao bairro, que considero o início do processo de reconhecimento pelas pessoas do Pium. Como Rodrigo teve pneumonia concomitante ao fim da construção da casa, ela cuidou dele lá, e começou a fazer a receita de lambedores nessa época. A casa onde mora é muito próxima ao rio onde décadas atrás a quantidade de roças familiares ribeirinhas era maior, e as doenças decorrentes do trabalho nesse ambiente também:

F: Seu (nome não compreensível) marido de Dona Emira, pai de Daniel. Eu queria muito bem a eles dois, e eu comecei a fazer esses remédios pra ele, esse lambedor.

C: Ele tinha o que mesmo?

F: Tinha aquela tosse bem forte, tipo uma bronquite. Só a vida do paú aqui, ele trabalhava no paú, esse movimento de água direto, de terra molhada direto. Eu fazia os lambedor e ele dizia "ô lambedor bom danado, faça outro lambedor daquele pra mim”. Aí eu comecei já a fazer as coisas assim, só que eu não vendia, eu dava por amizade tal e o meu filho de pequeninho quando eu pra morar aqui, que tem 27 anos hoje. Com idade de sete meses ele teve uma pneumonia, eu morava em Natal e me passei pra cá, ele tava internado. Sabe com o que eu curei a pneumonia desse menino? Com lambedor de tamarindo. (F., entrevista, 08/08/2015, Parnamirim).

Durante esses 27 anos que se mudou para o local, ela foi conhecendo as pessoas, desenvolvendo seu saber-fazer (DE CERTEAU, 1994) aprendendo novas combinações e preparos, assim como foi recebendo desafios dos conhecidos que ganhavam os preparos, para as diferentes enfermidades que apareciam. Em suas narrativas traz diversas experiências de doenças (LANGDON, 2014), que ocorreram tanto consigo, quanto com quem está a sua volta, enquanto agente facilitadora dos processos de cura presente nos itinerários terapêuticos (LOYOLA, 1984) dos que a rodeiam.

Nos levando a pensar sobre a concepção de doença nas camadas populares na realidade contemporânea brasileira fomos remetidos ao trabalho Saúde e gênero no bairro do Ibura de Parry Scott e Marion T. Quadros (2009) que mostra que:

As doenças citadas pela população são evidências dos problemas de 
saneamento (doenças de pele e verminoses), com o ambiente e o aparelho respiratório (cansaço e asma), ou aquelas associadas às dificuldades de convivência social diária e ao stress (dores de cabeça e doenças de nervos). São problemas recorrentes para os quais pode haver soluções imediatas, mesmo que paliativas e temporárias, através da intervenção e ação de familiares (normalmente seguindo orientações médicas que já fazem parte de um acervo de conhecimentos da população).(SCOTT; QUADROS, 2009, p.59).

Entretanto não há uma única significação da doença, médicos e pacientes têm diferentes premissas, elas contêm múltiplas compreensões, que podem estar envoltos no que Duarte (1986) chamou de problemas físico-morais, gerando diferentes perspectivas em relação ao tratamento (HELMAN, 1994). E o que Langdon (2014) traz quando aborda a experiência da doença é que a primeira avaliação é a familiar, é em casa que há o primeiro diagnóstico, para depois procurar um especialista terapêutico, que pode ser o médico, uma benzedeira, uma erveira, um farmacêutico ou mesmo uma outra pessoa que já passou por aquela determinada doença que foi percebida entre os parentes. Mas em geral se age com base nos preceitos da medicina oficial segundo o trabalho de Scott e Quadros (2009), e como pode ser visto quando Francisca diz que ao não saber de algo recorre aos livros de medicina alternativa que tem, como o Medicina de A a Z, Spethmann (2003), ou quando deixa claro que prefere que a pessoa já chegue a ela com o diagnóstico do médico, para ela apenas indicar o tratamento, como tratemos adiante.

É na interação entre a legitimidade das práticas médicas e populares, entre o saber local e o científico que podemos perceber a reação dela nos eventos-críticos (DAS, 1995) com os quais se deparou. Momento em que levou em consideração o conhecimento que já tinha gravado na memória de infância, os que as pessoas ao redor compartilhavam e as informações que pesquisou e aprendeu lendo livros de médico, de medicina alternativa e demais materiais sobre saúde que tinha acesso, remetendo à concepção de Barth (2000, p. 128-129) na qual os: "Eventos são o resultado do jogo entre a causalidade material e a interação social". De modo que traremos aqui o relato de vida de Francisca abordando a experiência dela em uma doença crônica, a Artrite Reumatóide:

C: Eu vi que esse problema de ossos dá mais em mulher. E quando foi que a senhora começou a sentir essa dor nos ossos? F: Eu comecei a sentir depois de uma queda que eu levei em 1982. Afetou bacia, fêmur e quadril. Começou a gravidade dai, nessa época eu morava numa granja, num tinha médico certo, num tinha tempo pra correr atrás e foi se agravando cada dia pior, quando foi agora, de 
2001 eu comecei a trabalhar foi que eu comecei a sentir a situação complicando, eu caminhava daqui pra Pirangi a pés. Uma baixa estação todinha, por que não tinha transporte, e a bixiga dos... não deixava a gente bater o cartão além do horário. E a gente tinha que ir caminhando pra num chegar atrasada, e num tinha transporte nessa época. Aí foi quando eu comecei as coisas foi se agravando, e sempre trabalho. E qual é a máquina que trabalha direto e num estraga uma peça? E a gente, e a peça que a gente estraga faz o que? Aí foi quando eu saí, passei o tempo, operei o pé, que foi a sequela de uma cirurgia. C: No acidente?

F: Foi do acidente que eu sofri, tive só a torsão do pé. Não quebrou, não fraturou, foi só torsão. Foi se agravando mas foi um cisto entre o dedão e o outro. E esse dedo foi estufado assim pra fora. Ainda hoje é torto, tá vendo? Isso aqui foi feito uma cirurgia daqui aqui. E foi botado um pino pra poder emendar esse osso que foi descolado pra poder tirar o cisto. Ai isso é tudo dormente, eu não sito nadinha. E fui caminhando e sempre trabalhando. Que eu nunca tive repouso.

(...)

F: [Até 2009] Eu trabalhava de babá e de doméstica, e a noite cuidava da menina. Ainda passei três anos, saí pra fazer tratamento, não aguentei mais continuar.

C: A senhora fez tratamento de que?

F: Problema de ossos. Em 2013 deu degenerativo meu problema de ossos, tenho três ressonâncias. Mas graças a deus quando eu comecei, acordei pra vida e vi que remédio natural vale melhor do que remédio de médico eu resolvi a me tratar como Deus quer e como consente. Mas se eu tivesse naquele tempo como eu tava, em 2010 eu já tava aleijada, já tinha atrofiado. Num conseguia tirar uma blusa, tinha que alguém ajudar, os braços não ajudava a subir. Num tirava o sutiã. (F., entrevista, 23/12/2015, Parnamirim).

Essa série de eventos-críticos narrados geraram uma ruptura biográfica (BURY, 1982), nesse momento em que ela estava numa crise de Artrite Reumatóide não aguentou mais continuar exercendo tais trabalhos braçais e precisou parar. Em outras entrevistas detalha que em 2010 estava com muitas dores e não conseguia trabalhar, na época estava como empregada doméstica e babá na casa de um tenente da base aérea, que pediu que ela se afastasse pois percebeu que não tinha mais condições de executar as tarefas. Nesse ano, ela conseguiu o auxílio-doença pelo INSS, mas no fim do ano ele foi acabou. Em 2011, sua irmã estava doente de câncer de mama, ela se dedicou a essa cuidado e a irmã ajudava a mantê-la durante esse período, mas, em 2013, ela faleceu. Durante esse tempo Francisca procurava uma fonte de renda, de tal forma que trabalhou cozinhando caranguejo para vender junto ao seu filho que até hoje vende frango assado. Todavia, ainda assim, ela não conseguia se manter economicamente. No fim de 2012, houve um curso de sabonetes que ela não pôde fazer por estar cuidando da irmã, mas uma amiga que fez o curso três meses depois, lhe entregou o livro com as 
instruções para produção, disse para ela comprar o material e passou uma tarde ensinando a preparar. Nos três meses seguintes, ela foi se preparando para iniciar a produção, comprando o material com o dinheiro que rendia da venda de caranguejos. Em meados de 2013 ela começou a produzir os sabonetes artesanais, mudando apenas uma coisa da instrução que recebeu. No livro ensinava a fazer com essências, mas uma pessoa do Clube de Mães deu a dica de fazer com a infusão de quinze dias das plantas medicinais no álcool. Desde então, ela vem produzindo os sabonetes para vender.

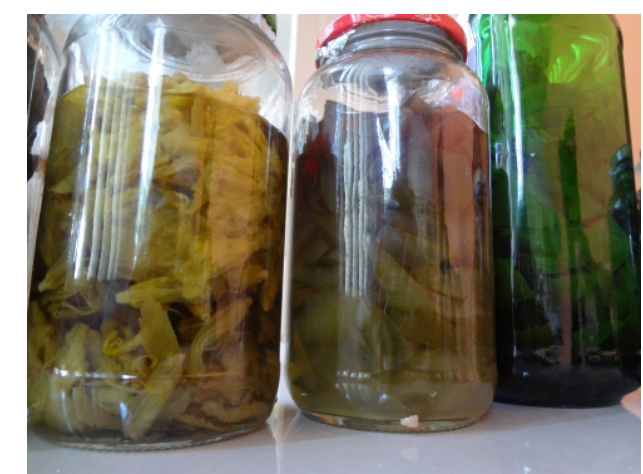

Foto 06: Ervas da terra em infusão no álcool para a preparação dos sabonetes. Da esquerda para a direita xanana, babosa e neem. Acervo pessoal. Maio de 2016.

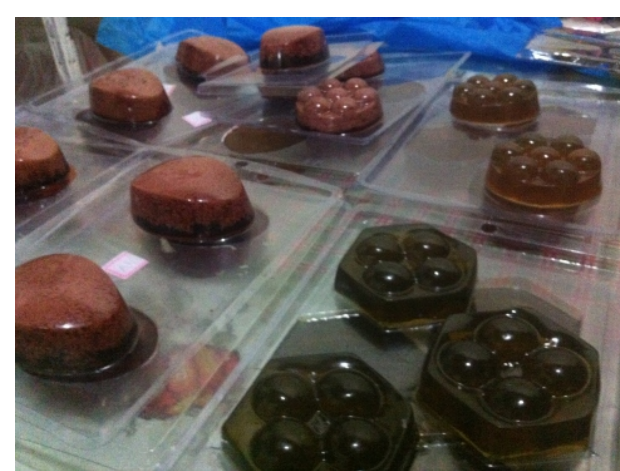

Foto 07: sabonetes artesanais ainda na fôrma: Acervo pessoal. Abril de 2016.

Foi a partir da venda dos sabonetes que ela resolveu comercializar os lambedores e garrafadas. E na situação em que se viu doente buscando o tratamento, ela diz, "acordei pra vida e vi que remédio natural vale melhor do que remédio de médico" se remetendo à descoberta dos efeitos colaterais da alopatia no organismo, tal como a cirrose medicamentosa que afeta o fígado, ou mesmo a gastrite que pode desenvolver no estômago devido ao contato da mucosa com o remédio de médico. Isso levou a que ela percebesse que aquilo que é visto como natural não agride tanto ao corpo, fazendo-a aguentar a ingestão de remédios algumas vezes desagradáveis ao gosto. No relato abaixo compreendemos qual o tratamento ela desenvolveu:

\section{C: O que foi que a senhora tomou?}

F: Quando eu comecei, ele me deu esse livro em 2011, quando eu comecei a ver como é que a coisa funcionava o que era capaz, o que causava aquele problema, aí eu comecei com os remédios. É sucupira, aroeira, pau ferro ele é rico em cura de coluna, inflamação na coluna. Tomei muito o coisa para bucite. Tomei muito aquela bicha grande, como é que chama? Coité, passei mais de ano tomando coité. 


\section{C: Em garrafada ou em chá?}

F: Isso é, só toma quem tem coragem. Que é um remédio tão ruim, tão ruim que eu nunca encontrei um pior do que aquele. É cozinhado sem água, só o legume dentro dele verde, tira e bora pra cozinhar em fogo baixo e ele solta aquela água, tipo feijão preto, aquela gororoba que você coa e bota na geladeira pra ficar tomando todo dia, $5 \mathrm{ml}$, duas vezes. Mas tinha que tapar o nariz e já tinha um negócio na mesa pra tomar por que não suportava o gosto. É ruim, mas eu tomei um ano e resolveu. (F., entrevista, 23/12/2015, Parnamirim).

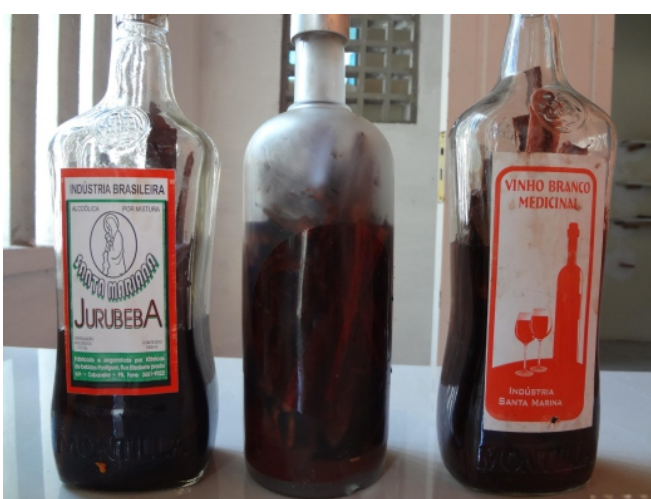

Foto 08: Garrafadas em processo de preparo para venda com as ervas secas, no vinho branco e na jurubeba. Acervo pessoal. Maio de 2016.

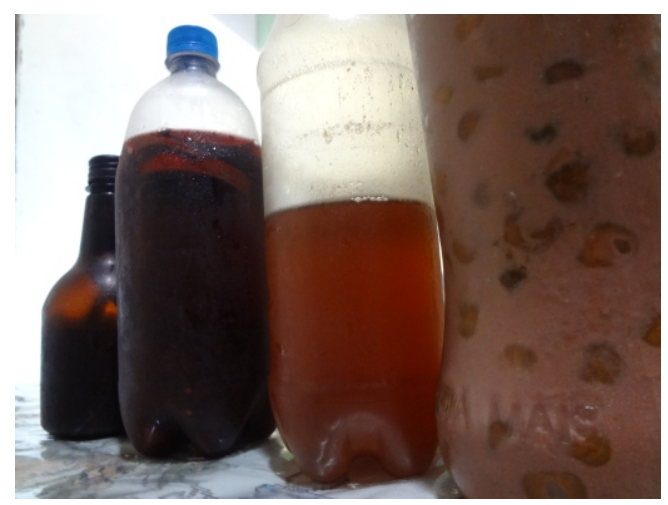

Foto 09: Preparados da Doutora Raiz para consumo próprio. Acervo Pessoal. Maio de 2016.

No conhecimento comum, o amargo já é atrelado ao sabor do preparado medicinal, como um chá de boldo, mas a peculiaridade dessa receita que ela tomou durante um ano é seu forte odor, segundo seu próprio filho, "se botasse merda pra cozinhar fedia menos". Com esse exemplo, entendemos como essa medicina popular se distancia da assepsia da medicina científica, que produz remédios dentro de uma concepção de higiene (DOUGLAS, 1976) e que ao delimitar o que é puro e impuro, também determina regras sociais de convivência, cuidado e percepção do próprio corpo.

F: Meu problema é degenerativo na minha ressonância, eu tenho três ressonâncias. "Dr. Fernandes o que danado é degenerativo?" Eu gosto de perguntar pra conhecer, saber a história e o que eu sinto também. "Dona Francisca, degenerativo" ele é bem calmo sabe? "É um problema que não tem solução, a solução é se agravar a cada dia, vai ter que estar aqui todo mês olhando pra mim e acompanhando sua medicação" "Dr. Fernandes, Deus é o maior". E fui-me embora. Só vou pra ele quando eu ia precisar de um atestado pra perícia, pra ir pro médico, pra renovação de alguma coisa. Ai comecei a fazer fisioterapia, faça 10 assim, 10 pra fora, magoou foi mais minha filha, não tive condições de continuar. Tỉnha dia que eu saía de lá pior do 
que chegava.

CE no outro dia num tava melhor?

F: Na continuação do tempo ficava pior, eu digo, "Vou mais não". O pior é que eu tomo meus remédios, tomo as garrafadas que eu faço. Mas esse problema quando vem ele num fica bom não. Alivia as dores. Mas num fica bom não. Quem tem problemas de ossos não fica bom não. (F., entrevista, 23/12/2015, Parnamirim).

A interação com o saber médico que existe na vivência de Francisca ocorre na busca pela compreensão da doença e na medida em que ela precisa obter direitos, ou exames, mas a credibilidade dada por ela às práticas alopáticas é pouca. Ela disse que não recorreu aos remédios que o médico passou, e produz diversas combinações de plantas para auxiliar no tratamento, ou pelo menos para apaziguar os sintomas da enfermidade. De modo que ela coloca em xeque a legitimidade desse saber que se propõe universal:

O rótulo de "científico" atribui uma espécie de sacralidade ou imunidade social ao sistema ocidental. Ao se elevar acima da sociedade e de outros sismas de saber e simultaneamente excluir outros sistemas de saber da esfera do saber fidedigno e sistemático, o sistema dominante cria seu monopólio exclusivo. Paradoxalmente, os sistemas de saber considerados mais abertos é que estão, na realidade, fechados ao exame e à avaliação. A ciência ocidental moderna não deve ser avaliada, deve ser simplesmente aceita.

(...)

Desse modo, o saber científico dominante cria uma monocultura mental ao fazer desaparecer o espaço das alternativas locais, de forma muito semelhante às monoculturas de variedades de plantas importadas, que leva à substituição e destruição da diversidade local (SHIVA, 2003, p. 24-25).

Nessa reflexão sobre as interseções entre o conhecimento científico e popular que existem na prática da Doutora Raiz, traremos outros casos e experiências que evidenciam como se dá essa interação:

F: Nunca mais tomei remédio de pressão, meu pai faleceu, uma coisa que eu me admirei, que pedi muito a Deus eu não assisti o velório da minha mãe, da minha irmã que faleceu, da minha tia, chega minha pressão me bota pro hospital, eu num vejo mais sepultamento de ninguém da família, eu num suporto a pressão. E esse de papai não, eu soube de noite, tive só uma reação na hora que soube a notícia, travou as pernas, o treme treme. O menino "Já tomou seu remédio hoje mãe?" era me preparando pra notícia. Falei "Não, vou tomar agora" Botei logo uma chaleira no fogo, capim santo, amora e camomila, fiz uma garrafa de chá, passei a noite todinha sem dormir, passei a noite todinha tomando chá, fiz uma garrafa quente e outra gelada. Levei pra lá "Menina, o que é isso?" "É chá gelado e chá quente, mas é do mesmo chá” "ai que chá bom, que chá gostoso é 
esse?" digo é "camomila e amora é tranquilizante" Todo mundo tranquilo, eu num senti uma dor de cabeça. Acredita? E eu digo a todo mundo, "olhe como as coisas movimenta diferente" Por que eu não tinha como, me dava uma tremedeira, uma coisa ruim, uma coisa tomando meu fôlego, eu morrendo se acabando, corria me dava amansa leão no hospital, diazepan, saia doida, lerda, num sabia nem o que tava fazendo, pra vir pra casa. Agora através dos meus chás, tá ali o remédio, eu não tomei o remédio que o médico passou. Minhas garrafadas, meus sucos, dentro de casa eu não paro de tomar. (F., entrevista, 12/05/2016, Parnamirim)

Esse trecho de entrevista nos remete à essa ligação com a medicina oficial, a tensão e a coexistência com os saberes populares. Devido à pressão alta seguida de dores de cabeça, ela ia para o hospital onde eram prescritos remédios que têm um efeito colateral muito forte, tal como o diazepan. A sensação posterior não era vista como de bem-estar. Então, a partir da sua experiência da doença, ela resolve não recorrer ao tratamento biomédico, mas opta pelo uso de chás, que são uma mistura de variedades vegetais que têm a mesma propriedade medicinal, a de acalmar. À medida em que os utilizou em si mesma, passou também a recomendá-los para pessoas com quem se relaciona, em ambientes sociais e até rituais, por exemplo velórios, nos levando ao que Turner (2005) aponta quando coloca que aqueles que já passaram por determinada doença se tornam uma referência e até mesmo especialistas terapêuticos, e numa análise mais contemporânea podemos pensar sobre como o ativismo no campo do cuidado em saúde que possibilita a formação de um doente profissional (EPSTEIN, 2007) que pode rejeitar, indagar ou corroborar com as concepções praticadas na medicina científica. Ela já contou mais de uma experiência de levar os chás aos funerais e as pessoas que consumiram mudarem de atitude, melhorando consideravelmente a partir do consumo do chá, que é tão aceito socialmente que não há receio para tomá-lo.

Portanto nessa interação com a medicina científica, é notória uma legitimidade concomitante à uma desconfiança, presente nas narrativas dela. Essa relação mostra que o alcance do discurso médico-científico está atrelado ao acesso, mas tem a capacidade, em certa medida, de transcendê-lo. De tal forma que tais valores e discursos podem ser incorporados mesmo que não haja contato constante com a prática médica oficial. Mas muitas vezes essa a prática médica também passa por uma avaliação na qual seu conhecimento e prática são postos em cheque, baseando-se principalmente em critérios como: amabilidade do profissional de saúde, explicação detalhada sobre a doença, prescrição de exames e eficácia do tratamento. 
F: Tem uma muda de anador, tem pé de menta aí, a muda de malva rosa tá linda as malvas, foi o que me levantou, quando eu cheguei fiz um chá de sabugueiro malva rosa e... Qual foi a outra coisa, meu deus? Mirra e Colônia, fiz um chá bomba, tomei dois dipirona e me deitei. Suei igual a porta de geladeira. Tem remédio melhor do que os meus? Eu vou pro hospital ver o que? Olhar pras caras dos médicos de joelho que num olha nem pra gente, meu neto foi lá comigo, de madrugada, com febre, 40 graus, tomou um banho aqui chegou lá com 38. Ele pegou um germe, coçava coçava chega sangrava. A médica passou um remédio pra alergia, "Rodrigo isso não é alergia" "Tá bom, a senhora quer saber mais do que o médico" Agora deu. Ele chegou aqui eu botei gelo, ele chega pedia mais, ele passou dormiu aqui, quando acordou chega a pele tava calminha. Passando pomada não resolvia de nada. Foi pro Antônio Prudente, chegou com 40,5 graus a medica disse que "Isso aqui nunca foi alergia", era um germe tomando de conta do menino dando febre alta era do germe e a gente foi pra esses burro aqui de Pirangi "Não aqui é só gesso".

C: É muita imprudência.

F: Se você tá precisando ir no médico, tá com o ouvido doente, uma dor de cabeça, ele não vai examinar seu ouvido, vai só passar o remédio pra passar a dor? Gente, é uma irresponsabilidade muita desumanidade um negócio desse. "Mãe, vamo pro hospital" "Vou não" Sabe quando eu vou pro hospital? Quando eu to com a pressão alta. Ai eu vou, mas essas dosesinhas dos médicos, vou nada. (F., entrevista, 01/04/2016, Parnamirim).

Em seu relato, ela coloca que evita ir aos serviços de saúde, prefere se utilizar da variedade de plantas medicinais que tem em casa, em torno de sessenta espécies que estão descritas em meu trabalho monográfico (BEZERRA, 2016), pois conhece suas funções, tomando-os com consciência da ação no corpo e, em casos de febre, associa ao consumo de remédios alopáticos como a dipirona. Pois como foi colocado por Luc Boltanski (2004), os casos de febre são os que mais preocupam as camadas populares, eles indicam que a doença é grave, e o fato é que em relação ao seu neto ela tinha um diagnóstico diferente da médica que o atendeu em Pirangi, mas seu filho descredibilizou seu conhecimento, afirmando que ela queria saber mais que a médica. Como a criança não melhorou, na verdade a febre subiu com o passar do tempo, eles procuraram outro médico (como pondera Boltanski (2004), há a troca de médico quando o tratamento não é eficiente), o que evidenciou um itinerário terapêutico. E no atendimento do Hospital Antônio Prudente, localizado no bairro do alecrim, em Natal/RN, foi constatado o que Francisca suspeitava, que era um germe. Logo, é devido a esses diagnósticos equivocados, inclusive pela generalização da ideia de alergia, e pela falta de atenção dos 
médicos para com o paciente, que a ida ao hospital só ocorre, para muitas pessoas das camadas populares, numa emergência. Francisca pondera que, diversas vezes, eles só medicam para a dor, apaziguando o sintoma, e não curando a doença, criticando a falta de atitude investigativa dos médicos que muitas vezes não pensam as enfermidades de modo mais integrado com a realidade que o paciente está inserido.

Além de outros métodos de tratamento, o advento da modernidade estabeleceu diferentes regras de higiene e de relação com o corpo, produzindo também uma situação hierárquica a partir do médico, visto como o detentor do saber, enquanto o paciente é concebido como leigo. Como essa relação é legitimada, as pessoas dão mais credibilidade quando o médico é atencioso, explica o que causa, como se desenvolve a doença. Mas esse interesse em saber o que acontece com o seu corpo também é decorrente da importância da necessidade de classificação, tal como Lévi- Strauss (1976) colocou, embora as pessoas apenas captem, às vezes, alguns termos médicos e os utilizem sem a devida propriedade. É necessário nomear o que acontece no corpo e, atualmente, ninguém mais indicado para exercer essa função do que o médico.

É com base nessa discussão que pensamos aqui a legitimidade do saber médico em sua prática terapêutica, tal como Francisca nos faz perceber. Ela diz que prefere que a pessoa já tenha ido ao médico e venha a ela com um diagnóstico, pois, assim, ela pode sugerir o tratamento adequado, sem precisar adivinhar o que a pessoa tem. Ela também sabe os diversos exames que eles podem requerer para conferir a existência de determinada enfermidade, o que ela também coloca como um método válido para se obter um diagnóstico.

F: [Contando seu diálogo com Rodrigo]"Mãe, teu remédio é meio doido mas serve vissi??" Ele tava com gastrite, "Mãe tudo que eu como parece que tá inchando" "Vá na médica, Rodrigo" Aí eu fui na médica tirei a ficha, ele foi pro médico, a médica passou olha a ruma de remédio, aqueles comprimido grande, aí ele chegou e disse "Tá aqui mãe, a médica disse que eu tô com gastrite" eu disse "Meu filho, você num vai tomar esses remédio não" "Lá vem a senhora, mainha. A médica num passou? A senhora quer saber mais que a médica, mãe?" "Rodrigo, gastrite é uma coisa que você tem que fazer primeiro uma endoscopia pra saber se você tá com gastrite, num é um sintomas que dá que você vai saber que tá com aquele problema não, você tem que saber o diagnóstico pra saber o que é" "Eu num vou tomar não que a senhora tá dizendo que não é pra eu tomar" ficou aquele alvoroço "Tenha calma" Aí eu mandei ele suspender a farinha, que ele comia muita farinha. 


\begin{abstract}
C: De trigo?
F: Não, no almoço normal. Aí comecei a fazer chá verde, aquele chá mate e passava com limão. Ei, pense num negócio gostoso, de manhãzinha antes dele tomar café eu fazia esse chá, o chá mate com limão e o chá verde. "Tome, Rodrigo" "Lá vem a senhora com as suas gororoba" “Tome logo!" "Ei mãe, vishi maria, to melhor vissi?” Era um dia de jogo e eu lá com uma garrafa de chá "Rodrigo, olhe, tome isso daqui" Aí os meninos começaram a tirar onda com ele, aí eu dizia "Rodrigo, esse daqui mata e esse daqui cura, ó" com a cerveja, "Eita, Rodrigo chegou a mamadeira" ele bem jovem mas grande, eu sempre tratei como uma criança, por que os filhos da gente nunca cresce... "Minha mãe eu num sei não, pra tudo ela tem uma solução" Minha nora mora aí, aí ela diz "Eu mesma nunca mais comprei remédio pra Mariana não, quando ela tá doente eu digo, vá la na tua avó" Entendeu? (F., entrevista, 01/04/2016, Parnamirim).
\end{abstract}

Nesse caso, quando seu filho vem se queixar de dores, ela mesma o encaminha para o médico, e vai ao posto de saúde tirar a ficha para ele ir a consulta. Mas quando ele volta com a avaliação da médica e a receita dos remédios recomendados, ela prontamente recusa que ele adira a esse tratamento. Por saber que apenas se trata de uma gastrite a partir do exame de endoscopia, ela imediatamente deslegitimou a prática médica e aconselhou ao filho a mudar seu hábito alimentar. Ela desempenhou o papel de mãe e de cuidadora da saúde da família, reforçando o que trouxemos anteriormente sobre o protagonismo da mulher enquanto cuidadora. Preparou, dia após dia, a receita que conhece para empachamento. De início, ele se negou a tomar. Disse que seus remédios eram doidos, mas logo percebeu a eficácia. Assim acontece também com a nora de Francisca que, sempre que sua filha adoece, a encaminha para os cuidados da avó. Quando fui a sua casa no dia 12 de maio de 2016, Mariana estava gripada, Francisca gritou de dentro de casa chamando para ela ir tomar o lambedor e prontamente a menina foi e ficou lá alguns minutos observando nossa conversa.

Isso mostra que os valores morais em que ela e sua família estão imersos se vinculam ao conhecimento comum que é base das práticas terapêuticas atuais. $O$ consumo de remédios alopáticos prescritos pelos médicos varia de classe e segmento social, dos próprios recursos financeiros para compra dos medicamentos, mas também do que se compreende sobre o efeito dos remédios no corpo, e do modo do tratamento. Algumas pessoas esperam um resultado rápido, na ação médica, outros desacreditam que tratamentos rápidos são eficazes, pois determinados remédios só escondem os sintomas, mas a doença permanece necessitando de um acompanhamento contínuo até obter a cura. 
Entretanto é comum nas suas narrativas a busca pela legitimidade deste saber local a partir da medicina científica, tanto na utilização de livros de medicina alternativa, quanto na afirmação que aprovou a garrafada na farmácia de manipulação:

F: Olhe o ipê roxo, o angico, a quixabeira são ervas que ele rompe problema de próstata, de útero, ovário, aí ele rompe. Aí o de miomas eu aprovei na farmácia de manipulação, acredita?

C: A senhora deu a fórmula pra eles?

F: Eu fui procurar como eu conseguia o remédio pra um colega que tava com um tal de pubis, é uma dor que ele sente na parte genital. E eu fiz duas garrafadas pra ele e não conseguia, ele dizia "Dona Francisca, tô do mesmo jeito". Um colega do meu filho, muito legal ele. Aí eu fui na farmácia de manipulação, aí o rapaz disse "Olhe, mande ele vir aqui, por que a gente trabalha..." Eu disse a ele "Eu faço garrafada". Aí ele disse: "Olhe a gente trabalha com uxi amarelo, que é uma casca de planta. O barbatimão que é outra casca de planta, e o unha de gato". Essas três ervas ele faz a cápsula pra cisto e miomas. E eu trabalho com essa cápsula pra cisto e miomas, só que eu faço a garrafada. Eu quero ver essas garrafadas que eu faço alguém chegar e dizer: "Menina, eu tomei sua garrafada mas não serviu de nada" (F., entrevista, 08/08/2015, Parnamirim).

Nessa fala, percebemos tanto uma busca para melhorar o produto, para que ele tenha a eficácia desejada, quanto pela legitimação dos elementos utilizados para esses fins terapêuticos, havendo um diálogo com os clientes, que comunicam quando não faz o efeito esperado, possibilitando refazê-los e melhorá-los, sendo afirmado por ela, então, que os produtos que ela faz e comercializa têm garantia. Nos remetendo à discussão de Mauss (2003) sobre magia e eficácia, e ao aspecto mais relevante da sua compreensão de tratamento: a fé, o acreditar que aquilo funciona, atrelado ao conhecimento. Esse sistema de saber local que ela vivencia é presente no habitus (BOURDIEU, 2004) e o reconhecimento deste acontece também nos locais que trabalhou:

F: Quando eu trabalhava no Vilage do Sol, um dia a hóspede chegou pra minha colega se era fácil dela encontrar um pé dessa babosa, uma folhinha. Aí ela disse "Fran, tu que tem muito remédio em casa, tu num tem babosa?" "Tem" "Que a hóspede perdeu o dela no avião e ela não se separa de babosa" Aí no outro dia eu levei a babosa e disse a Marliene "Pergunta a ela qual é a finalidade que ela não se separa do pé de babosa", ela disse "Minha filha, é o colírio que eu uso!"

C: Ela fazia como?

F: Tira aquela pelezinha grossa e passa no jeitinho assim no olho e passa só a baba. Ela disse que não tem colírio melhor do que a babosa. E a água do caroço da romã, acaba com catarata.

C: O caroço da romã precisa nem da polpa? 
F: Só o caroço mesmo, pegue o caroço e esprema aqui no olho, arde um ardorzinho mas de repente passa. Tinha uma senhora aqui que num sei como ela fez mas diz que bateu com o cabo do pente no olho, e a fralda direto no olho que tava escorrendo a água, chegou a nora "Dona Francisca, a senhora sabe dos remédios aí, me dê um remédio pra minha sogra que ela tá com o olho ardendo,tá tá cor de uma fita vermelha o olho dela" é até a mulher de Vando do caranguejo. Eu ensinei a ela a história da babosa, ela levou, aí com uns três dias eu tinha um barzinho nessa época aqui, ela chegou pra tomar uma e falou bote uma aí pra mim, "Mulher, me diga uma coisa, que remédio milagroso foi aquele que a senhora me deu? Por que olhe, tá com três dias, óh meu olho como é que tá, tô mas nem usando minha fralda" O problema é você acreditar que a coisa funciona. (F., entrevista, 08/08/2015, Parnamirim).

Nesses casos, o aprendizado das ervas que curam veio com as pessoas que ela conheceu por meio da experiência da doença. O saber que emerge é repassado e, por mais que ela ainda não vendesse os seus produtos na época desses fatos narrados, já havia o reconhecimento das pessoas do seu saber com as plantas medicinais. Constantemente ela deixa claro que a possibilidade da sua eficácia e cura, vem junto com a fé. Em suas falas, o acreditar é enfaticamente reforçado, nos levando a refletir sobre a concepção do chamado efeitoplacebo:

Efeito psicológico, fisiológico ou psicofisiológico de qualquer medicação ou procedimento prescrito com intenção terapêutica, independente dos efeitos farmacológicos da medicação, que opera através de mecanismo psicológico (...) É portanto a confiança na eficácia por parte de quem recebe e/ou administra uma substância ou procedimento placebo que pode produzir efeitos psicológicos e fisiológicos (HELMAN, 1994, p.177).

Tendo isso em mente, compreendemos que quando ela diz "O que importa é a fé da pessoa saber que vai funcionar" há uma inter-relação entre a intenção terapêutica dela e a confiança dessa eficácia por parte de quem recebe. Confiança essa que coloca Francisca enquanto Doutora Raiz, legitima seu saber com as ervas da terra, e se mescla com a capacidade de cada um que a procura de acreditar na possibilidade da cura. Essa somatória constitui a eficácia terapêutica (TAVARES; BASSI, 2012) que encontramos nas experiências narradas por ela:

F: As vezes num é nem o remédio é só a fé, as vezes você tá tomando um remédio e dizendo "Isso vale nada, não vou tomar isso mais não" num tem fé, sua fé não existe. Tem uma senhora aqui, a tia de Cacau, Cacau do mototáxi, nasceu um negócio aqui na mão dela, já tavam suspeitando que era um começo de CA que foi pra Pirangi, 
mandaram para o Arioclécio não mexeram, mandaram para o Luís Antônio lá foi, chegando lá disseram "Não, num vou tocar nisso daqui não, vou encaminhar a senhora pra ir pra Liga". Isso foi o ano passado, aí ela Lenira que é a menina que mora bem aqui, que tem um lanchinho bem aqui na frente, "Francisca, Anita tá com a mão só tu vendo, num tá mais nem caminhando, vai lá" Aí eu fiz que nem sabia do problema, cheguei lá "Dona Anita, nunca mais vi a senhora caminhando" "Minha irmã, olhe como é que tá minha mão" Aquela coisa assim, sabe como é que tá uma verruga mole aquela coisa desenvolvendo. "Dona Anita, mulher, a senhora tem fé em Deus?" "Tenho muita, minha filha" "Apois vamo fazer um teste, a senhora pega a babosa prenete bem em cima da sua mão, acabar passe o soro limpe todo excesso ou água oxigenada, depois que a senhora desconcentrar ele passe o sabonete de aroeira e deixe na sua mão" "Minha fia será que vai surtir efeito?" "Homi, use!" Aí passou, é muita coisa pra mim encaixar aí eu não gravo muita coisa, passou e as meninas disseram "Você viu tia?" "Não" "Por que ela a querendo lhe ver" encontrei com ela e ela disse "Minha irmã, você não sabe o quanto eu tenho pra lhe agradecer!" (F., entrevista, 08/08/2015, Parnamirim).

Essa experiência da doença, que aborda também o itinerário terapêutico de uma pessoa da comunidade, demonstra o percurso pelos hospitais públicos da região e a relação com a vizinhança e familiares para colaborar no processo de cura dessa senhora. Além disso ela explica que só a fé não é o suficiente para superar a doença, dando a deixa sobre a intenção terapêutica de cada um para a eficácia do tratamento. A fénas narrativas dela, relaciona Deus e conhecimento, é colocada como primordial para a cura, além de ser exposta como estímulo para o uso desses remédios naturais. Ela pondera que qualquer medicamento que for administrado, se a pessoa não acreditar no que está utilizando, não vai surtir efeito. Expondo um imbricamento no qual a fé, que pode ser analisada como a crença no conhecimento com as ervas da terra, se torna necessária para uma eficácia terapêutica.

É importante frisar, como foi dito no início, que nesse artigo foram articuladas categorias analíticas com categorias locais, e empoderamento é uma das que se configura como categoria analítica. Não há em suas narrativas o uso desse termo, que ela não havia escutado até o momento em que perguntei para ela sobre isso, mas ao ser questionada, frisou:

F: O que importa é a fé da pessoa saber que vai funcionar. As pessoas que usam e vem trazer o resultado isso pra mim é o crescer, é uma satisfação!

Nem todo mundo que faz permanece, quando vê que tá tendo saída, 
só quer ganhar, compra coisas baratas. Do jeito que comecei, faço do mesmo jeito. Eu quero ver o efeito que a situação acontece!

Quando você acredita nunca fica pra você sempre passa pra alguém. Eu e Karl, a gente fez aquele elo de conhecimento.

Regina quando me encontra diz "Adoro falar com você, parece que tem alguma coisa que reativa em mim". (F., entrevista, 12/12/2016, Parnamirim).

O resultado trazido pelas pessoas que usam fazem com que ela confirme o efeito dos seus produtos, e ela coloca que isso é crescer. A satisfação está em perceber que houve uma eficácia terapêutica. O acreditar é permeado pelo compartilhar, não se trata da fé em si, mas de reconhecer a potencialidade daquelas ervas que muitas vezes passam despercebidas pela falta de conhecimento, por não reconhecer uma farmácia em cada esquina. E tal elo de conhecimento estabelecido com outros produtores é o que permite o fortalecimento, crescimento e expansão do seu saber-fazer. Os produtores e pesquisadores citados nas suas narrativas, também residem no bairro do Pium, mas bem como Francisca não são nativos do local. Mas trabalham sob o mesmo ponto de vista, a partir da fitoterapia, utilizam métodos fisio-químicos de extração das propriedades medicinais das plantas, e assim como ela levam seus produtos para as feiras regulares que ocorrem no Pium. De certo, é nesse espaço de sociabilidade que ocorrem as trocas, que as relações são estabelecidas e saberes são afirmados.

Na etnografia Saber Local e Práticas Terapêuticas de uma Doutora Raiz (BEZERRA, 2016) foi detalhado esse campo depossibilidades (VELHO, 2003) que a rodeia. Abaixo um recorte fotográfico da Ferinha de Frutas do Pium, um dos pontos de referência do bairro:

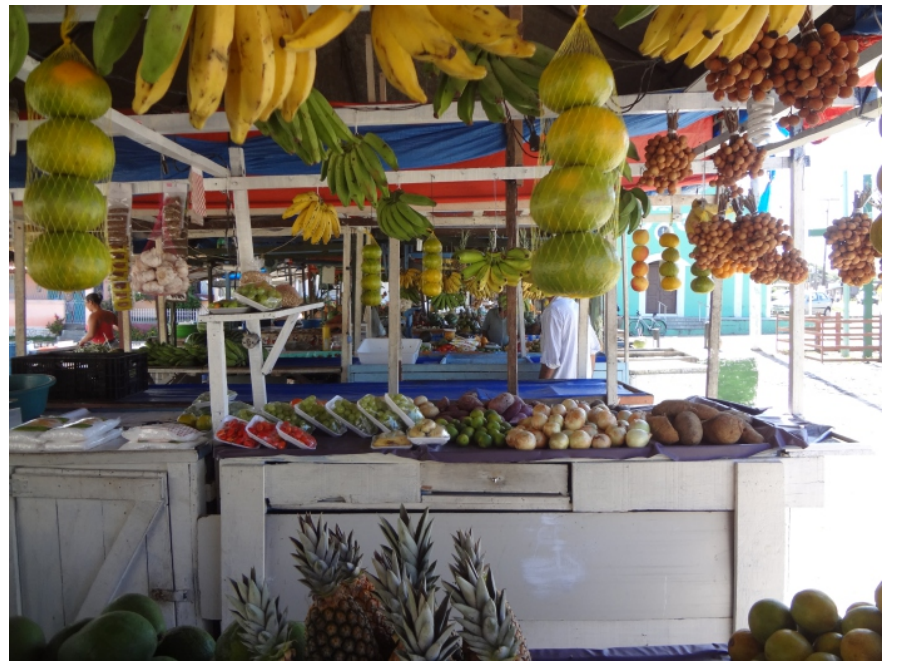

Foto 10:Feira de frutas no Pium. Ao longo do dia reúne ciclistas, turistas e moradores locais. Acervo pessoal. Maio de 2016. 


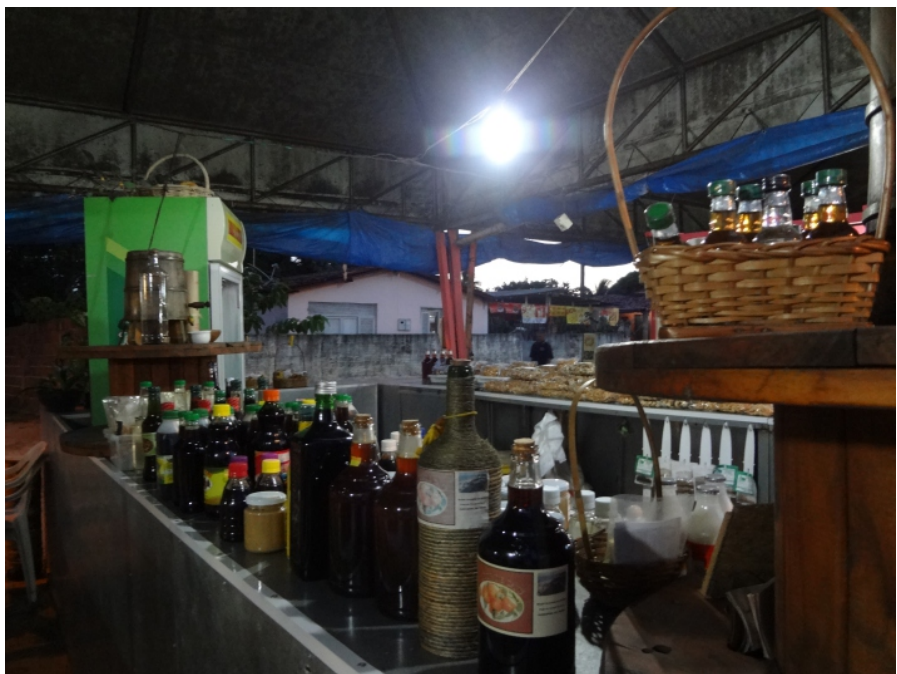

Foto 11: Feira de frutas também comércio de mel, lambedores, ervas naturais e refeições. Acervo pessoal. Maio de 2016.

Por fim, se faz necessário pensar esse imbricamento entre o conhecimento, reconhecimento e empoderamento. Pois devido a esse saber-fazer (DE CERTAU, 1994) advindo de um sistema local de saber e do interesse contínuo por conhecer mais, ela estabeleceu uma rede de contatos com pessoas que compram seus produtos ou também são produtores e pesquisadores, e com isso fortalece sua atividade produtiva na prática cotidiana, havendo um empoderamento. No texto de Rhéaume (2009) podemos ver como as interações entre sujeitos podem colaborar com o empoderamento, termo interpretado e designado como reapropriação de seu poder (CESAF, 1999; GUITIERREZ, 1995; LE BOSSÉ et al., 1996; NINACS, 1996; WALLRSTEIN; BERNSTEIN, 1994 apud RHÉAUME, 2009), o autor explicita que este conceito é interligado com a atividade produtiva pois na medida em que há o empoderamento, há o reconhecimento, há o desenvolvimento de competências, da estima de si, de uma consciência social crítica, e de um quadro de relações igualitárias. Fazendo com que nesse processo haja a construção também de uma identidade e memória histórica, individual e coletiva (RHÉAUME, 2009, p. 170). 


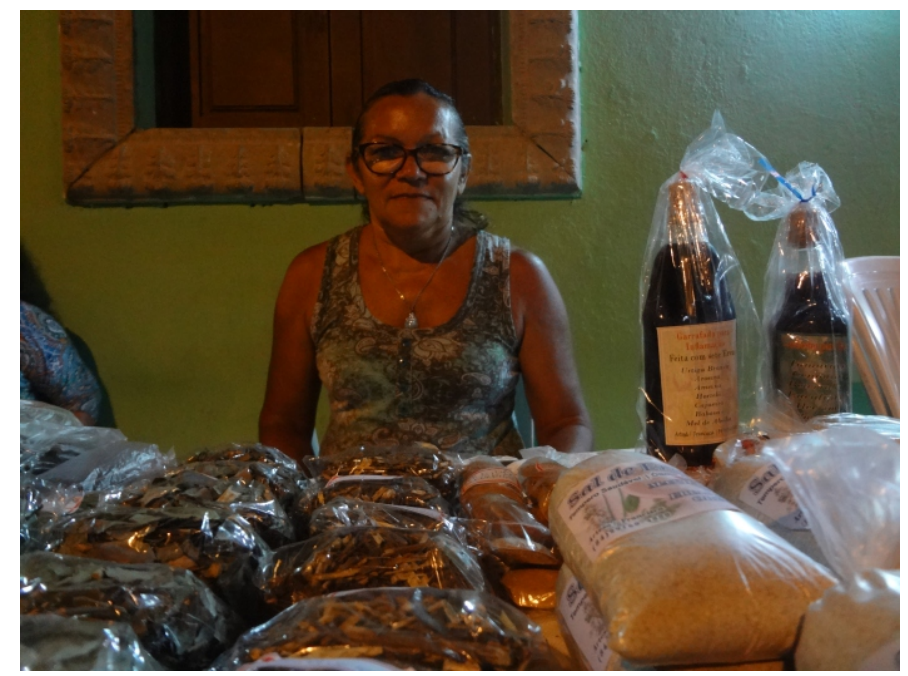

Foto 12: Francisca no evento Pium Artes que ocorre próximo à feira de frutas, ao lado da igreja católica do bairro. Acervo pessoal. Novembro de 2015

Assim a gratidão (termo utilizado por ela mas que pode ser lido sob a ótica de Mauss (2003) também como dádiva) que as pessoas demonstram devido a eficácia terapêutica de seu trabalho, e a interação com outros produtores colaboram para esse processo de reapropiação de seu poder, para o desenvolvimento de competências e construção de uma identidade e memória, como foi apontado por Rhéaume (2009). A inserção em uma rede de produtores colabora para a comprovação dessa eficácia terapêutica, e para a expansão desses saberes que emergem na interação com a comunidade local e científica.

\section{Considerações Finais}

Nesse ínterim, pensar sobre processos de cura com ervas da terra é levar em consideração um campo de possibilidades em expansão. Pois tendo em vista que executar as práticas de cuidado imbricadas no habitus (BOURDIEU, 2004) enquanto atividade produtiva a ponto de ser reconhecida como especialista terapêutica é recente. Há que se considerar que a apropriação desses saberes, lidos enquanto locais ou (que se pretendem enquanto) globais, populares ou científicos também é recente.

Com efeito, o contato com demais produtores e com as pessoas que a procuram enquanto uma erveira estimulam e alargam seu conhecimento. Quebrando com o primeiro plano da violência: a invisibilidade (SHIVA, 2003). Os produtos estão sendo testados (e aprovados) de tal forma ocorre um colapso com saber dominante. No qual as 
capacidades latentes nos sistemas locais de saber, encontrados nessa pesquisa etnográfica excedem o que foi explanado neste artigo. A saber, a percepção da potencialidade medicinal das plantas é uma das capacidades que a constituem enquanto uma Doutora Raiz. Em outras palavras, perceber uma farmácia em cada esquina, é relacionar-se com o ambiente conhecendo as ervas que curam e não como ervas daninhas.

Portanto, o empoderamento desenvolvido a partir do uso desse conhecimento desse senso comum, atrelado à apropriação do saber médico-científico, pode ser observado como um dos fatores para a eficácia terapêutica (TAVARES; BASSI, 2012) da prática dessa Doutora Raiz. Haja vista que as pessoas que a procuram, por vezes, chegam a duvidar do efeito daquele produto, mas é também a partir da intenção terapêutica expressada pela especialista que se elaboram elementos para a eficácia do tratamento. Tais fatores abordados como crença e conhecimento, indicam que a apropriação desse saber passa pela percepção da agência do sujeito no processo de cura, a fé a que ela se refere é voltada tanto para a crença nas práticas tanto da medicina popular quanto científica, e as experiências da doença expressadas nas narrativas aqui abordadas mostram o imbricamento dessas as práticas nos âmbitos de cuidado em saúde com as ervas da terra.

\section{Notas}

1. Pesquisa etnográfica realizada sob a orientação do professor Dr. Carlos Guilherme do Valle, defendida em junho de 2016, no curso de ciências sociais na Universidade Federal do Rio Grande do Norte.

\section{Referências bibliográficas}

ALBERTI, Verena. Ouvir Contar: Textos em História Oral. Rio de Janeiro: Editora FGV, 2004.

BARTH, Frederick. O guru, o iniciador e outras variações antropológicas. Rio de Janeiro: Contra Capa Livraria, 2000.

BEZERRA, Cristina. Saber local e práticas terapêuticas da Doutora Raiz: uma pesquisa antropológica sobre medicina popular e crença. Trabalho de Conclusão de Curso, Graduação em Ciências Sociais, Universidade Federal do Rio Grande do Norte, 2016.

BOLTANSKI, Luc. As classes sociais e o corpo. São Paulo: Paz e Terra, 3 a ed. 2004. 
BOURDIEU, Pierre. A produção da crença: contribuição para uma economia dos bens simbólicos. São Paulo: Zouk, 2004.

. L'illusion biographique. Actes de la Recherche en Sciences Sociales,

1986.

BURY, Michael. Chronic illness as biographical disruption. In: Sociology of Health and Ilness. Inglaterra: Vol. 4, No 2, Julho, 1982.

DAS, Veena. Critical events: An anthropological perspective on contemporary India. Delhi: Oxford University Press, 1995.

DE CERTEAU, Michel. A invenção do cotidiano: 1. Artes de fazer. Petrópolis, RJ: Vozes, 1994.

DOUGLAS, Mary. Pureza e Perigo. São Paulo: Perspectiva, 1976.

DUARTE, Luiz Fernando Dias. Da vida nervosa das classes trabalhadoras urbanas. Rio de Janeiro:J.Zahar, 1986.

EPSTEIN, Steven. "Patient groups and Health movements". In: Edward Hackett et alli. (eds.), New Handbook of Science and Technology Studies. Cambridge, MA: MIT Press. pp. 499-539. 2007.

GEERTZ, Cliford. Saber Local: novos ensaios em antropologia interpretativa. Petrópolis: Vozes, 2009.

HELMAN, Cecil G. Cultura, saúde e doença. Porto Alegre: Artes Médicas, 1994.

INGOLD, Tim. Estar Vivo: Ensaios sobre movimento, conhecimento e descrição. Petrópolis, RJ: Vozes, 2015.

LANGDON, Esther Jean. Os diálogos da antropologia com a saúde: contribuições para as políticas públicas. In: Revista de Saúde Coletiva, Rio de Janeiro, vol. 19, nº abril, 2014. Disponível em: http://dx.doi.org/10.1590/1413-81232014194.22302013. Acesso em: 15 de dezembro de 2016.

LÉVI-STRAUSS, Claude. O pensamento selvagem. In: A Ciência do Concreto. São Paulo: Ed. Nacional, 1976.

LOYOLA, Maria Andréa. Médicos e Curandeiros: Conflito social e saúde. São Paulo: DIFEL, 1984.

MAUSS, Marcel. Sociologia e Antropologia. São Paulo, Cosac Naify, 2003.

NÓBREGA, Jociara. Tecendo vivências e sentidos do câncer infantil: Família, 
Doença e Redes de Apoio Social em Natal-RN. Dissertação (mestrado) - Programa de Pós-Graduação em Antropologia Social, Universidade Federal do Rio Grande do Norte, 2011.

PINA CABRAL, João de; LIMA, Antónia Pedroso de. Como fazer uma história de família: um exercício de contextualização social. Etnográfica, Vol. IX (2), 2005.

RHÉAUME, Jacques. Relato de vida coletivo e empoderamento. In: TAKEUTI, Norma; NIEWIADOMSKI, Christophe (orgs.). Reinvenções do sujeito social: teorias e práticas biográficas. Porto Alegre: Sulina, 2009.

SCOT'T, Parry; QUADROS, Marion (orgs). A diversidade no Ibura: gênero, geração e saúde num bairro popular do Recife. Recife: Ed. Universitária da UFPE, 2009.

SHIVA, Vandana. Monoculturas da Mente: perspectivas de biodiversidade e da biotecnologia. São Paulo: Gaia, 2003.

SPETHMANN, Carlos Nascimento. Medicina Alternativa de A a Z. Uberlândia: Editora Natureza, 2003.

TAVARES, Fátima; BASSI, Francesca. Para além da eficácia simbólica: estudos em ritual, religião e saúde. Salvador: EDUFBA, 2012.

TRUCOM, Conceição. O Poder de Cura do Limão. Alaúde, 2014.

TURNER, Victor. Floresta de Símbolos Aspectos do Ritual Ndembu. In:

Muchona a vespa: intérprete da religião. Niterói: Editora Universidade Federal Fluminense, 2005.

VELHO, Gilberto. Projeto e Metamorfose: antropologia das sociedades complexas. Rio de Janeiro: Jorge Zahar Ed., 2003. 